\title{
Pemanfaatan Sukuk untuk Pembiayaan Proyek Infrastruktur pada Kementerian Pekerjaan Umum dan Perumahan Rakyat
}

\author{
Yanuar Pribadi ${ }^{a 1}$ \\ aPoliteknik Keuangan Negara-STAN, Jakarta \\ ${ }^{1}$ yanuar.pribadi@pknstan.ac.id
}

\section{INFO ARTIKEL}

\section{Riwayat Artikel:}

Diterima: 21-06-2020

Disetujui: 13-07-2020

\section{Kata Kunci:}

1. Utang Pemerintah

2. Sukuk

3. Pembiayaan Infrastruktur

Keyword:

1. Government Debt

2. Sukuk

3. Infrastructure Financing

\section{ABSTRAK}

\begin{abstract}
Abstrak: Penelitian ini membahas mengenai pemanfaatan utang pemerintah dalam bentuk Surat Berharga Syariah Negara atau Sukuk untuk membiayai proyek pada Kementerian Pekerjaan Umum dan Perumahan Rakyat (PU-PR). Kementerian PU-PR merupakan instansi yang mendapatkan alokasi anggaran proyek berbasis Sukuk paling besar dalam kurun waktu 2015-2019. Data penelitian berasal dari data sekunder berupa pagu anggaran dan realisasi pelaksanaan proyek dan dianalisis secara deskriptif dengan hasil wawancara dengan pelaksana proyek dan pengelola proyek Sukuk di Kementerian Keuangan. Hasil penelitian menggambarkan bahwa Sukuk merupakan salah satu sumber pembiayaan pembangunan infrastruktur pemerintah yang prospektif karena pasar keuangan syariah yang masih terus tumbuh dan berkembang. Namun demikian, kendala pada pelaksanaan proyek yang berimbas pada tambahan biaya utang perlu diminimalkan. Peningkatan kualitas perencanaan dan pengusulan proyek, penilaian kelayakan yang lebih ketat, serta mekanisme reward and punishment untuk menjamin proyek berjalan tepat waktu harus diterapkan oleh pihak-pihak yang berkepentingan sehingga pembiayaan proyek yang didanai dari utang terutama Sukuk dapat dilakukan dengan lebih efektif dan efisien.
\end{abstract}

\begin{abstract}
This study aims to discusses Government Islamic Debt Securities or Sukuk used to financing the projects at the Ministry of Public Works and Public Housing. The Ministry had the largest Project Based Sukuk allocation in 2015-2019. The research uses data from budget allocation and the realization of project implementation using descriptive analysis and combined with interviews from project implementers and debt managers. The result shows that Sukuk are prospective sources for government infrastructure development as the Islamic financial markets are still growing. However, problems on project implementation need to be minimized. Quality of project planning preparation should be improved, rigorous feasibility studies, and suitable mechanism of reward and punishment has to be implemented to ensure the effectiveness of the project.
\end{abstract}

\section{LATAR BELAKANG}

Indonesia merupakan negara berkembang yang mengandalkan pembangunan ekonomi yang berkelanjutan agar perekonomian tetap tumbuh. Anggaran Pendapatan dan Belanja Negara (APBN) sebagai alat kebijakan pemerintah diupayakan semaksimal mungkin untuk mewujudkan kesejahteraan rakyat sesuai tujuan negara yang terdapat dalam Undang-Undang Dasar. Perekonomian yang tumbuh stabil, diharapkan menjadi faktor pendorong bagi peningkatan Produk Domestik Bruto. Pada akhirnya nanti, kapasitas ekonomi negara diharapkan juga meningkat seiring peningkatan ekonomi secara agregat. Akan tetapi, keterbatasan sumber dana yang menjadi masalah klasik negara-negara berkembang masih menjadi hambatan bagi Indonesia dalam melaksanakan dan mengelola kebijakan ekonominya.

Permasalahan utama yang sedang gencar diselesaikan oleh pemerintah adalah masalah ketimpangan, baik ketimpangan dari negara lain, maupun ketimpangan yang terjadi antarwilayah di dalam negeri. Dalam rangka mengatasi ketimpangan tersebut, pembangunan untuk 
kegiatan yang bersifat produktif menjadi prioritas pemerintah sejak tahun 2015. Salah satu indikator terkuat dalam melihat ketimpangan pembangunan adalah adanya investasi penanaman modal asing (Firdaus, 2013). Kesenjangan infrastruktur yang terjadi antar provinsi yang terlihat melalui indeks Williamson berkaitan erat dengan kesenjangan ekonomi antar provinsi (Sukwika, 2018). Untuk menarik investasi, diperlukan kemudahan distribusi perekonomian yang antara lain didukung melalui infrastruktur yang tersedia dan berfungsi dengan baik. Sejak tahun 2015, pertumbuhan rata-rata anggaran infrastruktur pemerintah berada pada kisaran 12 persen. Hal ini terlihat dari anggaran infrastruktur yang terus meningkat dari tahun 2015 sebesar 256 triliun rupiah menjadi 400 triliun rupiah di tahun 2019. Kebutuhan pembangunan infrastruktur ini tentu tidak akan mampu untuk dipebuhi oleh pemerintah pusat. Oleh karena itu, kewenangan pemerintah daerah juga terus didorong agar dapat lebih berkontribusi dalam pembangunan infrastruktur melalui kerangka pendanaan Transfer ke Daerah.

Struktur APBN Indonesia memuat pembiayaan anggaran sebagai konsekuensi dari kebijakan defisit. Salah satu sumber penerimaan pembiayaan anggaran tersebut berasal dari utang. Pembiayaan utang ini dapat berasal dari pinjaman maupun Surat Berharga Negara (SBN). Pinjaman bisa berasal dari pemberi pinjaman dalam dan luar negeri, sedangkan SBN dapat bersumber dari Surat Utang Negara (SUN) maupun Surat Berharga Syariah Negara (SBSN). Karena sifatnya, pembiayaan yang berasal dari pinjaman dapat terkait langsung dengan proyek. Akan tetapi berbeda halnya dengan pinjaman, dana yang berasal dari SBN sebagian besar bersifat pembiayaan umum sehingga tidak terkait langsung untuk membiayai pembangunan proyek/kegiatan tertentu.

Kebutuhan pembiayaan infrastruktur di Indonesia sangat besar dan terus meningkat dari tahun ke tahun. Ketimpangan infrastruktur yang dimiliki Indonesia menurut laporan dari Asian Development Bank di tahun 2017 masih berkisar di angka 5 persen. Namun demikian, dari data APBN, ternyata alokasi anggaran infrastruktur yang berasal dari pembiayaan hanya sekitar 13,3 persen. Dengan demikian, pembangunan infrastruktur melalui alokasi anggaran pembiayaan belum dilakukan secara optimal. Di sisi lain, potensi sumber pendanaan anggaran infrastruktur melalui pembiayaan masih terbuka lebar. SBSN atau populer dengan sebutan Sukuk dapat menjadi sumber pendanaan yang memiliki prosepek cerah untuk membiayai pembangunan infrastruktur.

Penelitian ini menganalisis mengenai sumber pendanaan pembangunan infrastruktur yang berasal dari Sukuk dalam skema Sukuk Berbasis Proyek untuk membiayai pembangunan infrastruktur di Kementerian Pekerjaan Umum dan Perumahan Rakyat (PU-PR). Minimnya pemanfaatan utang terutama yang bersumber dari SBN seharusnya menjadi peluang bagi pemerintah untuk mencari alternatif pembiayaan infrastruktur. Karena pembiayaan infrastruktur yang dibiayai melalui Sukuk masih cukup sedikit jika dibandingkan dengan total kebutuhan pembiayaan infrastruktur pemerintah (Nurbiyanto \& Pribadi, 2020). Penelitian ini diharapkan dapat mengidentifikasi permasalahan yang menjadi faktor penghambat bagi pembiayaan pembangunan infrastruktur yang berasal dari SBN, khususnya Sukuk Berbasis Proyek. Dengan demikian skema pendanaan pembangunan infrastruktur melalui pembiayaan yang berasal dari Sukuk dapat berjalan efektif dan memberikan kontribusi signifikan dalam pembangunan infrastruktur pemerintah serta dapat lebih dikembangkan sebagai alternatif sumber pembiayaan pembangunan proyek infrastruktur pada Kementerian/Lembaga.

Sejak Undang-Undang Nomor 19 Tahun 2008 tentang Surat Berharga Syariah Negara diberlakukan, pemerintah menerbitkan Sukuk sebagai salah satu sumber pembiayaan. Perkembangan Sukuk di Indonesia terjadi dengan pesat karena animo transaksi keuangan syariah yang terus meningkat. Hal ini ditunjukkan dari pertumbuhan pasar keuangan syariah yang salah satunya berupa SBSN yang tumbuh dengan cepat di Indonesia (Fatah, 2011). Pasar sukuk terus diminati oleh negara-negara muslim dan non-muslim. Sukuk dapat dijadikan sebagai alternatif pembiayaan pemerintah seperti skema KPBU karena kemiripan mengenai adanya underlying asset (Nopijantoro, 
2017). Peningkatan permintaan Sukuk masih cukup tinggi karena Sukuk dipandang sebagai instrumen investasi yang aman dari risiko karena menggunakan underlying asset sebagai bagian dari akad atau perjanjian dalam penerbitannya. Penggunaan underlying asset dalam penerbitan Sukuk membuat peluang terjadinya risiko gagal bayar sangat kecil (Nasrullah, 2015).

\section{TINJAUAN PUSTAKA}

\section{a. Sukuk sebagai Instrumen Keuangan}

Sukuk merupakan istilah yang berasal dari bahasa Arab, yaitu bentuk jamak dari Sakk yang berarti dokumen/lembaran kontrak yang serupa dengan sertifikat atau note (Hariyanto, 2017). Sejarah perekonomian islam mencatat bahwa sukuk merupakan instrumen keuangan yang sudah digunakan sejak zaman kekhalifahan Islam. Bahkan, sukuk sudah digunakan dalam transaksi perdagangan baik yang bersifat domestik maupun internasional sejak sebelum abad ke-7 Masehi oleh para pengusaha/pedagang muslim. Sukuk umumnya dimanfaatkan oleh para pedagang muslim untuk mempermudah transaksi dan menjamin keamanan bagi pedagang itu sendiri.

Pada masa ketika belum mengenal kecanggihan teknologi dan sistem keuangan seperti saat ini, tentu akan sangat berbahaya bagi para pedagang jika membawa uang tunai dalam jumlah yang besar. Oleh karena itu, ketika para pedagang muslim tersebut hendak bepergian untuk berdagang di lokasi yang jauh, mereka tidak perlu membawa uang atau emas sebagai alat transaksi keuangan dalam jumlah yang besar. Para pedagang hanya perlu menitipkan uangnya pada orang/pihak yang berperan sebagai penerbit sukuk untuk ditukar dengan sukuk sebagai bukti kepemilikan uang. Dengan demikian, pedagang muslim cukup menggunakan sukuk sebagai alat pembayaran transaksi perdagangan yang dilakukannya.

Sukuk semakin berkembang sebagai alat transaksi perdagangan internasional seiring meningkatnya hubungan perdagangan antara para pengusaha muslim dengan para pengusaha dari Eropa. Pada Abad ke 18, kekhalifahan Turki Utsmani mulai menggunakan sebagai instrumen pembiayaan negara. Hal ini dilakukan seiring kekalahan dalam peperangan dengan Rusia sehingga Kekhalifahan Turki Utsmani harus membiayai defisit negaranya melalui penerbitan Esham (Amana, 2012).

Sebagai standar dalam penerbitan Sukuk, The Accounting and Auditing Organization for Islamic Financial Institution (AAOIFI) menerbitkan AAOIFI Sharia Standards Nomor 17 tentang Investment Sukuk pada tahun 2003. Melalui standar ini, sukuk didefinisikan secara komprehensif termasuk klasifikasi serta ketentuan penerbitannya. Sejak saat itu, perkembangan sukuk mengalami perkembangan yang pesat baik dari sisi jumlah/nominal maupun bentuk/jenis sukuk yang diterbitkan. Sukuk juga menjadi instrumen keuangan yang dimanfaatkan oleh negara-negara di dunia sebagai sumber pembiayaan. Bahkan negaranegara yang tidak berbasis penduduk muslim pun banyak memanfaatkan sukuk sebagai instrumen keuangan mereka.

Transaksi keuangan syariah saat ini semakin diminati oleh masyarakat. Kesadaran untuk melakukan transaksi keuangan menurut hukum syariah merupakan salah satu faktor pendorong tumbuh pesatnya instrumen keuangan syariah. Bahkan perusahaan-perusahaan dengan basis operasi konvensional pun mulai melirik instrumen keuangan syariah sebagai target untuk memperkuat investasi. Sejarah perkembangan sukuk di Indonesia dimulai ketika PT. Indosat Tbk. (ISAT) menerbitkan sukuk pada tahun 2002. Data reguler yang dilaporkan oleh Otoritas Jasa Keuangan (OJK) menyebutkan bahwa sampai dengan bulan Maret 2020, jumlah sukuk korporasi outstanding yang tercatat adalah sejumlah 146 sukuk dengan nilai outstanding sebesar hampir 30 triliun rupiah.

\section{b. Sukuk sebagai Sumber Pembiayaan Pemerintah}

Sukuk berbasis aset mulai dikembangkan oleh Bahrain dan Malaysia di tahun 1990. Struktur sukuk ini menarik perhatian khalayak karena dianggap potensial untuk diaplikasikan dalam rangka penerbitan instrumen syariah sekaligus sebagai alat untuk mengembangkan pasar modal syariah (Iqbal \& Mirakhor, 2008). Sukuk korporasi mulai diterbitkan di Malaysia pada tahun 1990 oleh Shell 
MDS. Sedangkan pemerintah Malaysia mulai menerbitkan sukuk pada tahun 2002 menggunakan dasar pedoman penerbitan berupa fatwa yang diterbitkan oleh Islamic Jurisprudence Council sebagai landasan syariah.

Di Indonesia, sejak badai krisis ekonomi menerpa di tahun 1998, pemerintah mulai menggunakan instrumen utang berupa SBN untuk membiayai defisit APBN. Keterbatasan sumber pendapatan negara menjadi faktor utama penyebab defisit pemerintah dalam keseimbangan umum anggaran. Keseimbangan umum anggaran merupakan selisih antara pendapatan dan belanja negara. Ketika pendapatan negara lebih sedikit daripada belanja negara, hal itu dikenal dengan istilah defisit. Defisit anggaran ini akan dipenuhi dari pembiayaan anggaran.

Penerimaan pembiayaan pemerintah sebagian besar berasal dari utang yang berbentuk SBN. Penerapan Undang-Undang Nomor 24 Tahun 2002 tentang Surat Utang Negara menjadi landasan pembiayaan utang melalui SUN. Kebutuhan pembiayaan yang semakin meningkat menuntut pemerintah untuk menyusun konsep baru pembiayaan selain SUN. Kemudian di tahun 2008, pemerintah mengatur regulasi mengenai utang melalui Sukuk seiring dengan potensi pasar keuangan syariah yang sangat luas di Indonesia.

Utang pemerintah yang berasal dari Sukuk juga terus meningkat meskipun nominalnya tidak sebesar SUN. Salah satu keunggulan Sukuk ialah adanya underlying asset sebagai jaminan sehingga pemerintah dapat menggunakan proyek yang akan dibangun sebagai jaminan. Dengan demikian, pemerintah dapat mencapai dua tujuan sekaligus yaitu dalam rangka memenuhi pembiayaan anggaran dan pembangunan proyek/kegiatan. Kebutuhan infrastruktur yang terus meningkat menyebabkan utang pemerintah terus mengalami peningkatan signifikan sejak tahun 2014 (Pribadi, 2017). Akan tetapi, pemerintah tentu tidak dapat mengandalkan penerbitan sukuk pada satu jenis atau varian tertentu. Inovasi diperlukan sehingga pemerintah dapat memperoleh sumber pembiayaan yang memadai sesuai dengan kebutuhan. Dalam hal ini, faktor yang berpengaruh bagi investor untuk membeli sukuk ialah jenis/karakteristik sukuk itu sendiri, baru diikuti oleh faktor agama, imbal hasil yang diharapkan serta keterbukaan informasi (Duqi \& Al-Tamimi, 2019). Oleh karena itu Sukuk berbasis proyek sebagai salah satu sumber pembiayaan infrastruktur di Indonesia perlu terus dikembangkan agar lebih diminati oleh para investor.

Sejak diterbitkan pertama kali pada tahun 2008, Sukuk telah mengalami beberapa inovasi dan perkembangan (DJPPR, 2016) sehingga terdiri atas beberapa jenis yaitu:

1) Sukuk Ritel

Sukuk Ritel merupakan Sukuk yang diterbitkan untuk dipasarkan kepada investor individu Warga Negara Indonesia melalui Agen Penjual. Pembelian minimal Sukuk Ritel sebesar 5 juta rupiah dengan tingkat bunga tetap yang dibayarkan secara bulanan. Sukuk Ritel merupakan jenis Sukuk yang dapat diperjualbelikan.

\section{2) Islamic Fixed Rate (IFR)}

IFR dipasarkan kepada investor institusi dengan cara lelang dan private placement dengan tenor lebih dari 1 tahun. Tingkat bunga IFR bersifat fixed dengan pembayaran secara semesteran dengan mata uang Rupiah. IFR juga dapat diperdagangkan.

3) Surat Perbendaharaan Negara Syariah (SPNS)

SPNS diterbitkan untuk dipasarkan kepada investor institusi dengan cara lelang dan private placement dengan mata uang Rupiah. Sebagai instrumen surat utang jangka pendek, tenor SPNS paling lama 12 bulan dengan imbalan berupa diskonto.

4) Sukuk Dana Haji Indonesia (SDHI)

SDHI merupakan Sukuk yang dipasarkan kepada investor institusi lembaga pengelola dana haji dengan cara private placement. Tingkat bunga SDHI bersifat fixed dan dibayarkan secara bulanan dengan mata uang Rupiah. SDHI merupakan jenis Sukuk yang tidak dapat diperdagangkan.

5) Project Based Sukuk (PBS)

SBSN PBS merupakan Sukuk yang dijual kepada investor institusi melalui lelang dan private placement, PBS menggunakan underlying berupa proyek maupun kegiatan APBN. Imbalan SBSN PBS berupa kupon yang bersifat fixed dan dibayarkan secara semesteran menggunakan mata uang Rupiah. SBSN PBS dapat diperdagangkan. 
6) Sukuk Valas

Sukuk Valas adalah Sukuk yang diterbitkan dalam mata uang asing di pasar internasional dengan metode bookbuilding atau private placement melalui penjualan Joint Lead Manager (JLM).

7) Sukuk Tabungan

Sukuk Tabungan dipasarkan investor dalam negeri melalui Agen Penjual. Pembelian Sukuk Tabungan minimal dua juta rupiah dengan tingkat bunga tetap yang dibayarkan secara bulanan. Sukuk Tabungan merupakan Sukuk yang tidak dapat diperdagangkan, tapi mempunyai fasilitas early redemption.

\section{METODE PENELITIAN}

Metode Penelitian yang digunakan dalam penelitian ini ialah analisis deskriptif dengan pendekatan kualitatif. Penelitian kualitatif bertujuan untuk mendapatkan makna yang mendalam berdasarkan data yang ada (Sugiyono, 2008). Penelitian kualitatif merupakan pendekatan penelitian untuk menganalisis topik permasalahan untuk memahami makna dari hasil wawancara maupun interpretasi terhadap suatu kejadian atau objek tertentu (Hennink, Hutter, \& Bailey, 2011) atau bersumber dari fenomena sosial atau kemanusiaan (Creswell, 2014). Dalam penelitian kualitatif, peneliti merupakan instrumen penelitian sehingga dapat memahami dan menginterpretasikan data secara mendalam.

Analisis deskriptif dilakukan melalui pendalaman teori, data maupun informasi melalui studi literatur baik berasal dari buku, jurnal ilmiah maupun regulasi pemerintah. Dalam penelitian ini, analisis kualitatif deskriptif dilakukan terhadap pelaksanaan pembangunan proyek infrastruktur yang dibiayai melalui skema Sukuk Berbasis Proyek. Analisis deskriptif dilakukan untuk menemukan permasalahan dalam pelaksanaan proyek infrastruktur di Kementerian PU-PR.

Data yang digunakan adalah data sekunder dari laporan pelaksanaan proyek yang dibiayai melalui Sukuk oleh Kementerian PU-PR antara tahun 20152019. Laporan pelaksanaan proyek tersebut terdiri atas data pagu dan realisasi proyek, baik yang diperoleh dari realisasi pada Sistem Perbendaharaan dan Anggaran Negara (SPAN) maupun data laporan pelaksanaan proyek yang disampaikan oleh Kementerian PU-PR ke Kementerian Keuangan.

Data sekunder tersebut kemudian dianalisis dan dibandingkan dengan konfirmasi terhadap pengelola proyek yang dibiayai melalui Sukuk di Kementerian PU-PR, dan Kementerian Keuangan. Kementerian PU-PR dipilih sebagai subjek penelitian karena mendapatkan alokasi anggaran yang paling besar banyak setiap tahun sejak mendapatkan pembiayaan proyek dari Sukuk dari tahun 2015. Realisasi anggaran digunakan untuk menilai kinerja pelaksanaan proyek. Kinerja pelaksanaan proyek dinilai oleh Kementerian Keuangan sebagai unit pelaksana pemantauan dan evaluasi proyek yang dibiayai melalui Sukuk.

\section{PEMBAHASAN}

Salah satu keunggulan SBN dibandingkan dengan pinjaman ialah bahwa SBN lebih fleksibel. Selain itu SBN bebas dari risiko intervensi kebijakan dari pemilik modal atau investor, berbeda dengan pinjaman yang berpotensi memiliki muatan politis dari pemberi pinjaman. Namun, kekurangan yang dimiliki oleh SBN ialah karena dana hasil penerbitan SBN tidak digunakan secara langsung untuk membiayai proyek. Oleh karena itu, pemanfaatan utang dari SBN tidak dapat dijelaskan secara jelas dan detail. Dalam hal ini, instrumen Sukuk berbasis proyek dapat menjadi solusi pemanfaatan utang yang berasal dari SBN.

\section{a. Perkembangan dan Outstanding SBN}

Utang merupakan suatu penerimaan yang harus dibayar kembali oleh penerima utang. Dalam proses memberikan utang tersebut, pemberi utang tentu memiliki motivasi-motivasi tertentu. Di atas telah disebutkan bahwa salah satu keunggulan SBN adalah bebas intervensi dari pemberi utang atau investor. Secara teknis, tingkat bunga SBN mengikuti tingkat bunga pasar dan jangka waktu pembayarannya dapat oleh pemerintah melalui pengelolaan portofolio dalam bentuk buyback atau debtswitch. Peran SBSN sebagai intrumen pembiayaan APBN dari waktu ke waktu menunjukkan peningkatan yang signifikan (Hariyanto, 2017). 
TABEL 1

OUTSTANDING UTANG PEMERINTAH

(dalam triliun rupiah)

\begin{tabular}{|l|r|r|}
\hline \multicolumn{1}{|c|}{ Jenis Utang } & Outstanding & Persentase \\
\hline $\begin{array}{l}\text { Pinjaman (Dalam } \\
\text { Negeri dan Luar } \\
\text { Negeri) }\end{array}$ & 764,48 & 16,0 \\
\hline Surat Utang Negara & $3.274,19$ & 68,5 \\
\hline $\begin{array}{l}\text { Surat Berharga } \\
\text { Syariah Negara }\end{array}$ & 740,62 & 15,5 \\
\hline Total Outstanding & $\mathbf{4 . 7 7 9 , 2 9}$ & $\mathbf{1 0 0 , 0}$ \\
\hline
\end{tabular}

Sumber: Kementerian Keuangan

Menurut laporan utang pemerintah yang telah diringkas dalam Tabel 1 di atas, outstanding utang pada bulan Desember 2019 ialah sebesar IDR 4.779 triliun. Meskipun secara nominal mengalami peningkatan jumlah outstanding setiap tahun, namun sebenarnya Sukuk masih memiliki porsi yang sedikit yaitu 15,5 persen atau sebesar IDR 740 triliun dari total outstanding utang pemerintah yang dikelola oleh Kementerian Keuangan.

Grafik 1 menunjukkan perkembangan outstanding SBN dari tahun 2002-2019. Utang pemerintah yang bersumber dari SBN terus meningkat sejak tahun 2002, dari sebesar IDR 570 triliun di tahun 2002 menjadi IDR 4.014 triliun pada tahun 2019. Outstanding Sukuk juga meningkat sejak diterbitkan tahun 2008 sebesar IDR 4,7 triliun menjadi sebesar IDR 740 triliun di akhir tahun 2019.

\section{GRAFIK 1 \\ JUMLAH OUTSTANDING SBN}

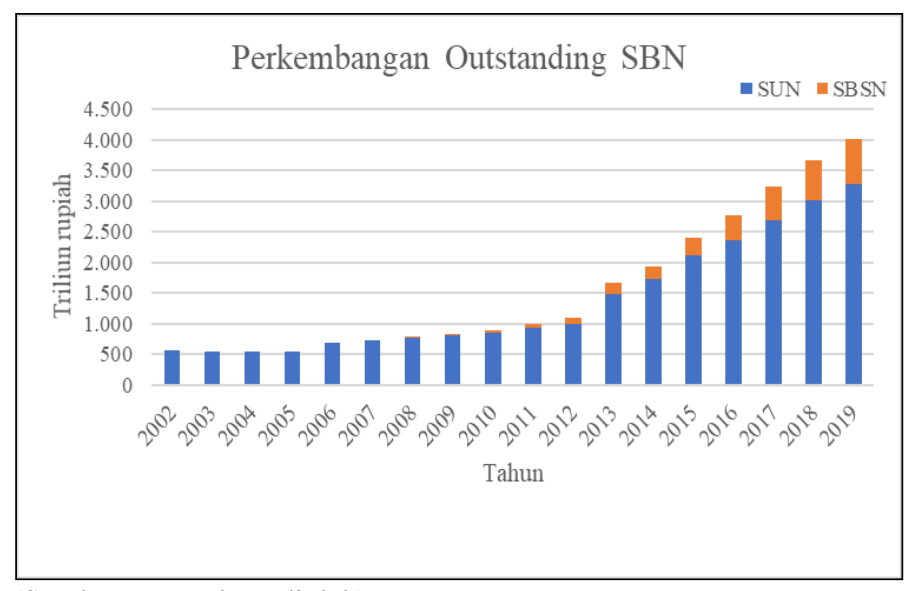

(Sumber:Kemenkeu, diolah).

\section{b. Sukuk untuk Pembiayaan Proyek}

Sebagai sumber utama pembiayaan pemerintah, pemanfaatan utang dari SBN perlu didefinisikan dengan baik sehingga masyarakat mendapatkan informasi yang jelas mengenai peruntukan utang tersebut. Bentuk pemanfaatan utang tersebut dapat berupa penggunaan sumber dana dari SBN untuk membiayai proyek/kegiatan tertentu, sehingga utang tersebut terkait langsung dan bersifat produktif karena pemanfaatannya jelas untuk mendanai pembangunan infrastruktur. Hal ini sejalan dengan kebutuhan infrastruktur yang masih akan terus dibangun beberapa tahun mendatang.

Meskipun kebutuhan pemanfaatan utang pemerintah sangat penting, namun faktanya outstanding utang yang berasal dari SBN digunakan untuk membiayai proyek hanya sebesar 414 triliun rupiah. Jumlah ini masih sangat sedikit jika dibandingkan dengan total outstanding utang pemerintah dari SBN yang berjumlah sekitar 4.014 triliun rupiah. Proyek pada kementerian/ lembaga yang dibiayai melalui penerbitan Sukuk terdiri atas proyek pembangunan infrastruktur, penyediaan layanan umum, pemberdayaan industri dalam negeri, serta pembangunan lain yang sesuai dengan program pemerintah.

Tahapan yang dilakukan oleh kementerian/lembaga selaku pemrakarsa proyek diawali dari pengusulan proyek oleh kementerian/lembaga kepada Kementerian Perencanaan Pembangunan Nasional (PPN)/Bappenas. Usulan proyek ini dilampiri dengan kerangka acuan kerja dan dokumen studi kelayakan proyek. Selanjutnya, Kementerian PPN/Bappenas melakukan penilaian kelayakan proyek dengan mempertimbangkan kesiapan dan kesesuaian proyek dengan Rencana Pembangunan Jangka Menengah, batas maksimum penerbitan SBSN dalam rangka pembiayaan, dan kesesuaian proyek dengan prinsip syariah.

Hasil penilaian kelayakan ini didokumentasikan dalam bentuk daftar prioritas proyek yang akan dibiayai melalui Sukuk untuk kemudian disampaikan Kementerian PPN/Bappenas ke Kementerian Keuangan dan instansi teknis yang mengusulkan proyek. Daftar prioritas proyek ini menjadi dasar alokasi proyek yang dibiayai melalui 
Sukuk dengan mempertimbangkan kebutuhan pembiayaan APBN secara keseluruhan. Alokasi anggaran proyek yang dibiayai melalui Sukuk ini kemudaian dituangkan dalam dokumen anggaran sebagai dasar pelaksanaan proyek sekaligus dasar penerbitan Sukuk. Mekanisme pembiayaan proyek melalui Sukuk sesuai bagan alur yang terdapat pada Gambar 1.

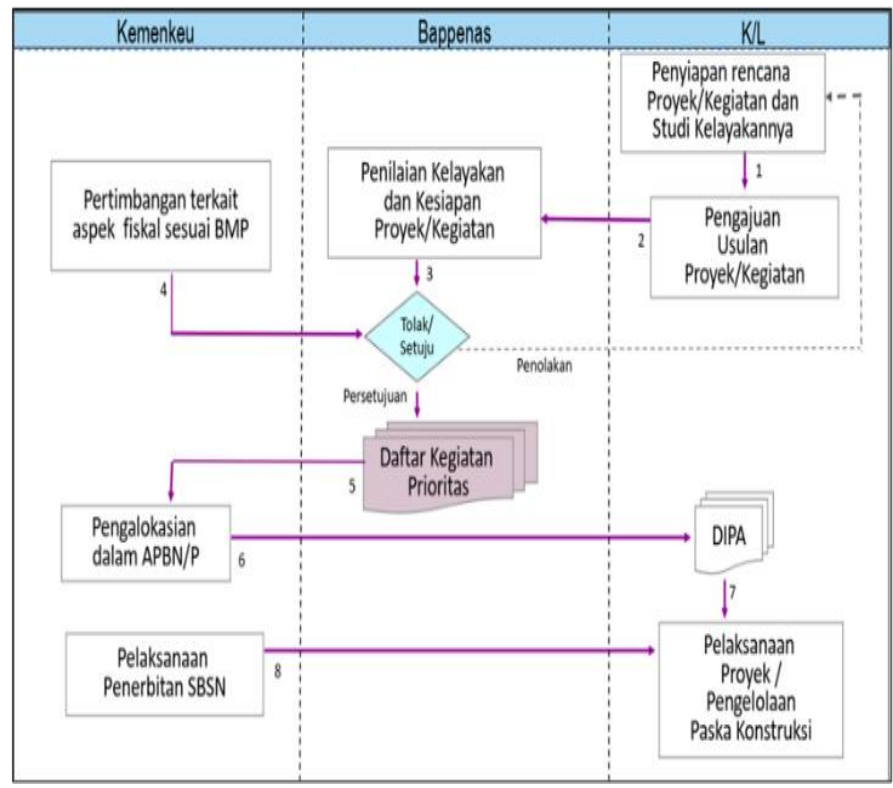

(Sumber: Kementerian Keuangan)

Gambar 1. Mekanisme Pembiayaan Proyek Melalui Penerbitan Sukuk

Meskipun porsi pembiayaan proyek melalui Sukuk masih sangat sedikit jika dibandingkan dengan jumlah total outstanding utang yang bersumber dari SBN, namun pagu anggaran Sukuk berbasis proyek terus meningkat. Di akhir tahun 2019, total anggaran proyek yang dibiayai melalui Sukuk sebesar 33 triliun rupiah. Menilik bahwa kebutuhan pembangunan infrastruktur yang masih terus berlangsung, maka Sukuk dapat digunakan sebagai sumber pembiayaan pembangunan infrastruktur terutama untuk pembangunan proyek infrastruktur pada kementerian/lembaga. Pemanfaatan utang akan dapat dilaporkan secara lebih transparan sehingga akuntabilitas peningkatan utang pemerintah dapat lebih terjaga. Perkembangan pagu anggaran proyek yang dibiayai melalui Sukuk dapat dilihat pada grafik berikut:

\section{GRAFIK 2. \\ PERKEMBANGAN PAGU ANGGARAN \\ PROYEK YANG DIBIAYAI MELALUI SUKUK}

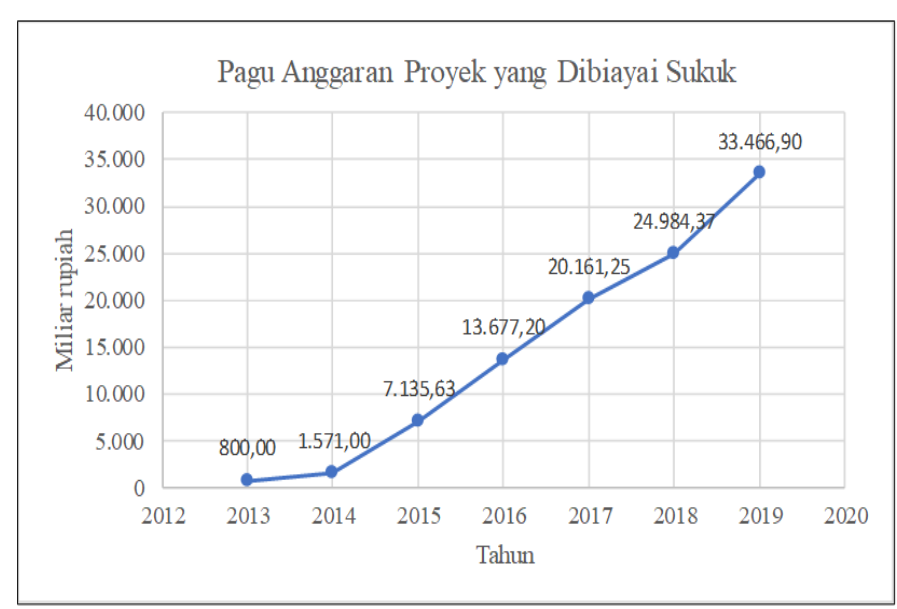

Sumber: Kemenkeu, (diolah)

\section{c. Pembiayaan Proyek yang dibiayai Sukuk di Kementerian PU-PR}

Berdasarkan data yang diperoleh dari Kementerian Keuangan, proyek yang dibiayai melalui Sukuk pada Kementerian PU-PR mulai dilaksanakan sejak tahun 2015. Ketika pertama kali mendapatkan alokasi anggaran pembiayaan proyek melalui Sukuk, Kementerian PU-PR mendapatkan alokasi dana sebesar 3,5 triliun rupiah. Jumlah tersebut terus meningkat hingga pada tahun 2019, Kementerian PU-PR mendapatkan alokasi dana sebesar 20 triliun rupiah. Alokasi anggaran tersebut digunakan untuk melaksanakan pembangunan infrstruktur di dua Direktorat Jenderal yakni Direktorat Jenderal Bina Marga dan Direktorat Jenderal Sumber Daya Air. Yakni untuk pembangunan dan rehabilitasi jalan negara, pembangunan jembatan, pembangunan embung/bendungan, dan konservasi daerah aliran sungai.

Realisasi penarikan dana untuk pelaksanaan proyek pada Kementerian PU-PR tidak pernah mencapai target. Di tahun 2019, realisasi bahkan tidak mencapai 80 persen dari pagu anggaran. Hal ini tentu harus mendapat perhatian bagi Kementerian/Lembaga teknis pelaksana proyek karena realisasi yang tidak sesuai dengan perencanaan berpotensi menimbulkan biaya tambahan dalam rangka pengadaan utang. Dana hasil penerbitan Sukuk yang ada di kas negara menjadi dana menganggur karena permasalahan 
yang terjadi pada saat pelaksanaan proyek dan memengaruhi realisasi penarikan dana proyek.

Permasalahan yang sangat sering terjadi dalam pelaksanaan proyek sangat bervariasi, tergantung dengan karakteristik proyek tersebut. Pada pembangunan infrastruktur berupa jalan dan jembatan, kendala yang menghambat antara lain proses lelang pengadaan untuk penentuan pemenang kontrak. Selain itu, kendala berupa iklim ataupun cuaca yang buruk serta lokasi proyek yang sulit terjangkau membuat akses untuk mengirimkan logistik dan peralatan proyek menjadi terganggu. Pelaksanaan proyek berupa pembangunan jaringan irigasi dan bendungan sering terkendala dalam pembebasan lahan, dan keterbatasan kontraktor yang mengalami kesulitan dalam menyelesaikan proyek karena kekurangan modal. Akibat permasalahan yang terjadi di lapangan tersebut, realisasi penarikan dana proyek tidak dapat berjalan sesuai rencana.

\section{TABEL 2.}

\section{PAGU DAN REALISASI ANGGARAN PROYEK YANG DIBIAYAI SUKUK KEMENTERIAN PU-PR TAHUN 2015-2019}

\begin{tabular}{|c|r|r|r|}
\hline Tahun & $\begin{array}{c}\text { Pagu } \\
\text { (Miliar) }\end{array}$ & $\begin{array}{c}\text { Realisasi } \\
\text { (Miliar) }\end{array}$ & $\begin{array}{c}\text { Persentase } \\
\text { Realisasi }\end{array}$ \\
\hline 2015 & $3.535,80$ & $3.327,75$ & $94,12 \%$ \\
\hline 2016 & $7.226,30$ & $6.097,27$ & $84,38 \%$ \\
\hline 2017 & $8.548,90$ & $7.269,30$ & $85,03 \%$ \\
\hline 2018 & $13.715,71$ & $11.487,28$ & $83,75 \%$ \\
\hline 2019 & $20.041,60$ & $15.925,04$ & $79,46 \%$ \\
\cline { 4 - 5 } & & &
\end{tabular}

Wawancara dengan pelaksana proyek maupun Kementerian Keuangan mengungkapkan bahwa kelemahan pada sisi perencanaan berupa penilaian kelayakan proyek harus diminimalisir sehingga pada saat pelaksanaan proyek tidak terjadi keterlambatan maupun permasalahan yang dapat berakibat pada rendahnya realisasi penarikan dana proyek. Selain itu, kriteria keberhasilan proyek juga perlu didefinisikan dengan jelas sehingga keberhasilan proyek tersebut dapat diukur dari besar dampak yang dirasakan oleh masyarakat dari pembangunan infrastruktur tersebut. Sebagai contoh, keberhasilan pembangunan bendungan atau rehabilitasi daerah aliran sungai tidak hanya diukur dari adanya output berupa bendungan atau daerah aliran sungai yang direhabilitasi, tapi juga harus diukur dampak dari pembangunan bendungan tersebut, apakah mampu meningkatkan dan memberikan kemudahan bagi petani dalam proses bercocok tanam mereka sehingga akhirnya mampu meningkatkan produktivitas hasil pertanian. Keberhasilan rehabilitasi daerah aliran sungai tidak hanya diukur dari panjang sungai yang direhabilitasi tetapi juga harus menyasar dampak yang dirasakan masyarakat secara nyata misalnya berkurangnya daerah terkena banjir atau luapan air sungai pada musim hujan.

\section{KESIMPULAN DAN SARAN KESIMPULAN}

Kebutuhan pembangunan infrastruktur di Indonesia masih akan terus berlangsung beberapa tahun ke depan untuk mengurangi ketimpangan dari negara lain maupun ketimpangan antarwilayah di dalam negeri. Namun kebutuhan pembangunan infrastruktur tersebut tidak dapat dipenuhi pemerintah secara langsung karena keterbatasan pendanaan. Konsekuensi dari defisit APBN karena belanja negara yang lebih besar dari pendapatan negara adalah diperlukannya pembiayaan APBN yang sebagian besar berasal dari utang. Meski sering disebut sebagai alat pendorong pertumbuhan ekonomi, pemanfaatan utang secara jelas sangat diperlukan sehingga utang yang dilakukan oleh pemerintah dapat diketahui secara transparan oleh masyarakat. Dengan demikian, publik dapat mengetahui dengan pasti penggunaan utang yang dilakukan oleh pemerintah.

Sebagai sumber utama utang pemerintah, SBN terutama Sukuk dapat dimanfaatkan untuk membiayai proyek secara langsung melalui skema pembiayaan proyek berbasis Sukuk. Potensi pasar keuangan syariah yang masih sangat terbuka ditambah dengan kebutuhan pembangunan infrastruktur merupakan kombinasi yang tepat untuk meningkatkan pemanfaatan utang melalui penerbitan Sukuk untuk pembiayaan proyek. Porsi Sukuk untuk membiayai proyek masih sangat sedikit, hanya sekitar 10 persen dibandingkan 
dengan total outstanding utang yang bersumber dari SBN.

Permasalahan dalam pelaksanaan proyek yang dibiayai melalui Sukuk merupakan tantangan yang perlu diantisipasi oleh pemerintah. Perbaikan mulai saat perencanaan dan pengusulan proyek, penilaian kelayakan oleh Kementerian PPN/Bappenas, proses pengadaan hingga tahap pelaksanaan pengerjaan proyek perlu dilakukan sehingga risiko keterlambatan yang menyebabkan realisasi penarikan dana tidak mencapai target dapat diminimalkan. Dengan demikian potensi tambahan biaya utang karena pelaksanaan proyek yang tidak tepat waktu dapat dikurangi. Selain itu, kriteria penilaian kelayakan proyek harus lebih didefinisikan secara jelas sehingga proyek infrastruktur yang dibiayai melalui Sukuk dapat memberikan dampak yang dirasakan oleh masyarakat secara langsung.

\section{DAFTAR RUJUKAN}

Amana, B. (2012, January 22-24). Sukuk: Shariah Guidelines for Islamic Bonds. (M. Nazri Bin Chik, Performer) Islamic Banking Operations and Regulatory Framework Workshop, Colombo, Sri Lanka.

Ayub, M. (2007). Understanding Islamic Finance, 1st Edition. London: Wiley.

Creswell, J. W. (2014). Research Design: Qualitative, Quantitative and Mixed Methods Approaches, 4th Edition. . California: SAGE Publication, Inc.

Duqi, A., \& Al-Tamimi, H. (2019). Factors Affecting Investor's Decision Regarding Investment in Islamic Sukuk. Qualitative Research in Financial Markets, Vol. 11 No. 1, 60-72.

Fatah, D. A. (2011). Perkembangan Obligasi Syariah (Sukuk) di Indonesia: Analisis Peluang dan Tantangan. $A L$ 'ADALAH Vol. X, No. 1, 35-46.

Firdaus, M. (2013). Orasi Ilmiah Guru Besar: Ketimpangan Pembangunan Antar Wilayah di Indonesia: Fakta dan Strategi Inisiatif. Bogor: Institut Pertanian Bogor.

Hariyanto, E. (2017). Efektivitas Penerbitan Sukuk Negara Sebagai Instrumen Pembiayaan APBN. Indonesian Treasury Review Vo. 2 No. 1, 79-98.

Hariyanto, E. (2017). Mengenal Sukuk Negara: Instrumen Pembiayaan APBN dan Sarana Investasi Masyarakat. Yogyakarta: Gava Media.

Hennink, M., Hutter, I., \& Bailey, A. (2011). Qualitative Research Methods, 1st Edition. California: SAGE Publications, Inc.

Iqbal, Z., \& Mirakhor, A. (2008). Pengantar Keuangan Islam. Jakarta: Prenada Media.

Kemenkeu. (2019, Desember 31). Laporan Kinerja Pinjaman, Hibah dan Surat Berharga Negara. Triwulan IV 2019. Jakarta: Kemenkeu.

Malik, A., \& Kurnia, D. (2017). Pengaruh Utang Luar Negeri Dan Penanaman Modal Asing Terhadap
Pertumbuhan Ekonomi. Jurnal Akuntansi, Vol. 3 No. 2, 27-42.

Nasrullah, A. (2015). Studi Surat Berharga Negara: Analisis Komparatif Sukuk Negara Dengan Obligasi Negara Dalam Pembiayaan Defisit APBN. JURNAL LENTERA: Kajian Keagamaan, Keilmuan dan Teknologi, Volume 1, Nomor 2,.

Nopijantoro, W. (2017). Surat Berharga Syariah Negara Project Based Sukuk (SBSN PBS): Sebuah Instrumen Alternatif Partisipasi Publik Dalam Pembiayaan Infrastruktur. Substansi, Vol. 1 No. 2, 390-406.

Nurbiyanto, N., \& Pribadi, Y. (2020). Surat Berharga Syariah Negara Berbasis Proyek Pada Kementerian Agama: Alternatif Pembiayaan Infrastruktur Pemerintah. Jurnal EKonomi dan Ekonomi Syariah (Jesya) Vo. 3 No. 2, 320-329.

OJK. (2020, April 17). Statistik-Sukuk-Syariah-Maret2020.pdf. Retrieved from Website OJK: https://www.ojk.go.id/id/kanal/syariah/data-danstatistik/data-produk-obligasi-syariah/Pages/StatistikSukuk-Syariah---Maret-2020.aspx

RI. (2002). Undang-Undang Nomor 24 Tahun 2002. Surat Utang Negara. Jakarta.

RI. (2008). Undang-Undang Nomor 19 Tahun 2008. Surat Berharga Syariah Negara. Jakarta.

RI. (2011). Peraturan Pemerintah Nomor 56 Tahun 2011. Pembiayaan Proyek Melalui Penerbitan SBSN. Jakarta.

Sugiyono. (2008). Metode Penelitian Bisnis. Bandung: Alfabeta.

Sukwika, T. (2018). Peran Pembangunan Infrastruktur terhadap Ketimpangan Ekonomi Antarwilayah di Indonesia. Jurnal Wilayah dan Lingkungan Vol. 6 No. 2, 115-130. 